\title{
Strategi Coping pada Penyintas Covid-19 Yang Mengalami Stigma: Sebuah Studi Fenomenologi
}

\author{
Rahma Ayuningtyas Fachrunisa \\ Fakultas Psikologi, Universitas Gadjah Mada \\ J1. Sosio Humaniora Bulaksumur, Sleman, DIY, Indonesia 55281 \\ rahma.ayuningtyas.f@mail.ugm.ac.id
}

\begin{abstract}
Abstrak
Permasalahan yang dihadapi oleh penyintas COVID-19 tidak hanya bersumber dari faktor fisik, namun juga faktor sosial. Studi ini bertujuan untuk mengeksplorasi pengalaman psikologis dan strategi coping pada penyintas COVID-19 yang mengalami stigma. Penelitian ini menggunakan metode fenomenologi dengan satu orang partisipan penyintas COVID-19 pertama di suatu daerah di Indonesia yang mengalami stigma berdasarkan kriteria yang telah ditetapkan. Hasil penelitian memunculkan tiga tema utama, yaitu: (1) tantangan sebagai penyintas COVID-19, (2) stigma terhadap penyintas COVID-19, dan (3) strategi coping penyintas COVID-19. Penelitian ini memberikan implikasi strategi coping yang adaptif dan kebijakan yang tepat untuk meningkatkan efektivitas penanganan COVID-19 di Indonesia dengan mempertimbangkan kondisi psikologis pasien.
\end{abstract}

Kata kunci: COVID-19; pengalaman psikologis; strategi coping

\begin{abstract}
The problems faced by COVID-19 survivors do not only come from physical factors, but also social factors. This study aims to explore the psychological experiences and coping strategies of stigmatized COVID-19 survivors. This study uses the phenomenological method with one participant being the first COVID-19 survivor in an area in Indonesia who experiences stigma based on predetermined criteria. The results of the study raised three main themes, namely: (1) challenges as COVID-19 survivors, (2) stigma towards COVID-19 survivors, and (3) coping strategies for COVID-19 survivors. This study provides implications for adaptive coping strategies and appropriate policies to increase the effectiveness of handling COVID-19 in Indonesia by considering the patient's psychological condition.
\end{abstract}

Keywords: COVID-19; psychological experiences; coping strategies

\section{PENDAHULUAN}

Coronavirus 2019 (COVID-19) masih menjadi permasalahan global yang dihadapi oleh lebih dari 150 negara (World Health Organization, 2020). World Health Organization (2020) menjelaskan bahwa terdapat 38.789.204 jumlah kumulatif kasus COVID-19 per 17 Oktober 2020 dengan total kasus kematian sejumlah 1.095.097. Cacciapaglia dkk. (2020) menyebutkan bahwa beberapa negara di dunia telah memasuki gelombang kedua COVID-19 yang membawa ancaman yang semakin meningkat, terutama di negara-negara Eropa. Meskipun begitu, terdapat beberapa negara pula yang masih menghadapi gelombang pertama COVID-19. Salah satu negara yang masih berada dalam gelombang pertama penyebaran COVID-19 adalah Indonesia, sebagai negara yang masih mengalami peningkatan jumlah kasus hingga 4.301 kasus setiap hari per 17 Oktober 2020 (Satuan Tugas Penanganan COVID-19, 2020). Indonesia menjadi negara dengan jumlah kasus terbanyak di Asia Tenggara per 17 Oktober 2020, yakni dengan total kasus sebanyak 349.160 kasus (World Health Organization, 2020) dan angka case fatality rate (CFR) sebesar 3,5\% (Satuan Tugas Penanganan COVID-19, 2020). Setiati dan Azwar (2020) menjelaskan bahwa kondisi tersebut semakin diperburuk dengan adanya fasilitas penanganan COVID-19 yang kurang memadai. 
Selain itu, Indonesia tidak hanya mengalami permasalahan fasilitas secara fisik dalam penanganan COVID-19, melainkan juga permasalahan sosial. Studi oleh Sulistiadi, Rahayu dan Harmani. (2020) menemukan adanya permasalahan sosial yang menjadi kendala penanganan COVID-19 di masyarakat, berupa stigma terhadap individu dengan COVID-19, keluarga pasien COVID-19, bahkan terhadap tenaga medis atau pihak-pihak yang menangani COVID-19. Stigma tersebut juga dapat berbentuk perilaku diskriminatif, berupa bentuk penolakan dan pengasingan individu di lingkungan pertetanggaan, pelemparan batu terhadap ambulans yang mengantarkan pasien COVID-19, hingga penolakan jenazah individu yang meninggal akibat COVID-19. Hal tersebut disebabkan oleh pemahaman yang tidak tepat ataupun lengkap terkait COVID-19 serta arahan yang tidak konsisten dari kebijakan pemerintah. Selain itu, studi tersebut juga memberikan penekanan bahwa stigma masyarakat yang diaosiasikan dengan COVID-19 dapat menjadi ancaman yang lebih buruk dibandingkan dengan COVID-19 itu sendiri.

Penelitian mengenai dampak stigma terhadap individu yang diasosiasikan dengan COVID19 telah dilakukan (Bhattacharya, Banerjee \& Rao, 2020; Guo dkk., 2020; Mahmud \& Islam, 2020; Ramaci, Barattucci, Ledda \& Rapisarda, 2020; Sun dkk., 2020; Sun dkk., 2021; Wango \& Wairire; 2020). Mahmud dan Islam (2020) menjelaskan bahwa stigma dapat berpengaruh pada risiko kesehatan individu, perasaan tidak aman dalam hidup, gangguan psikologis, perasaan tidak dihargai dalam lingkungan sosial, perpecahan keluarga, maupun ketegangan ikatan pertemanan. Ramaci dkk., (2020) juga melakukan studi untuk mengetahui pengaruh stigma terhadap kinerja tenaga medis yang menangani COVID-19. Ia melaporkan bahwa tenaga medis yang mendapatkan stigma cenderung memiliki tingkat stres yang lebih tinggi sehingga memengaruhi kinerja mereka. Selain itu, Bhattacharya dkk. (2020) juga menyebutkan bahwa stigma sosial dapat berdampak buruk terhadap proses penanganan maupun pencegahan COVID-19, yang ditandai dengan rendahnya angka pengecekan atau tes COVID-19 oleh individu dan tingkat kematian yang tinggi. Meskipun penelitian-penelitian tersebut tidak dilakukan di Indonesia, namun penelitian tersebut telah menggambarkan bahwa keberadaan stigma sosial terhadap individu yang diasosiasikan dengan COVID-19 telah menjadi penghalang tersendiri bagi penanganan kasus COVID-19 secara optimal, termasuk dengan memperburuk kondisi psikologis individu yang terkena COVID-19.

Berdasarkan gambaran keadaan tersebut, kondisi pandemi COVID-19 yang belum berakhir di Indonesia dan berbagai permasalahan dalam penanganan yang disertai dengan adanya permasalahan stigma sosial yang memperburuk penanganan pandemi, mengindikasikan perlu adanya persiapan yang lebih baik terkait ancaman jangka panjang dari COVID-19 di Indonesia. Meskipun begitu, penelitian terkait dampak psikologis COVID-19 cenderung ditujukan kepada tenaga medis (Ramaci dkk, 2020; Sun dkk., 2020) maupun masyarakat umum (Guo dkk., 2020; Wango \& Wairire; 2020). Sedangkan penelitian terhadap pasien COVID-19 yang telah dilakukan bertujuan untuk mengetahui kondisi psikologis pasien COVID-19 yang dirawat di Rumah Sakit (Sun dkk., 2021) dan belum mengeksplorasi dinamika psikologis pasien COVID19 dalam menghadapi stigma masyarakat secara langsung. Di samping itu, penelitian dengan tujuan tersebut juga belum dilakukan di Indonesia.

Dengan demikian, penelitian yang mengeksplorasi dinamika psikologis individu dengan COVID-19 yang menghadapi stigma dapat dilakukan untuk mengetahui cara atau strategi coping yang tepat dalam menghadapi stigma sosial sebagai stresor berat tambahan bagi penderita COVID-19. Gambaran mengenai strategi coping terhadap stigma yang telah dilakukan sebelumnya dapat menjadi pertimbangan empiris dalam upaya pendampingan psikologis pada pasien COVID-19 sekaligus pertimbangan bagi kebijakan publik berupa 
edukasi dan peningkatan pelayanan pada masyarakat terkait pandemi ini. Di samping itu, penelitian yang dilakukan dalam konteks masyarakat yang sama juga akan memudahkan proses implementasi dari intervensi selanjutnya yang akan dilakukan di Indonesia.

\section{METODE}

\section{Desain penelitian}

Penelitian ini menggunakan pendekatan kualitatif (Moleong, 2012). Sedangkan metode penelitian yang peneliti gunakan adalah Interpretative Phenomenal Analysis (IPA) dan berfokus pada pengalaman psikologis sebagai penyintas COVID-19. Pemilihan desain penelitian ini bertujuan untuk menjaga otentisitas pengalaman yang dialami partisipan. yakni melalui 8 langkah berupa: (1) persiapan, (2) memilih topik, (3) memilih metode IPA, (4) menentukan pertanyaan penelitian, (5) menentukan partisipan, (6) mengumpulkan data, (7) analisis data, dan (8) penulisan laporan (Smith dkk., 2009).

\section{Partisipan penelitian}

Peneliti menggunakan purposive sampling method. Kriteria inklusi partisipan meliputi: (1) pernah dinyatakan positif COVID-19, (2) pernah menjalani perawatan COVID-19, baik secara rawat inap ataupun rawat jalan, (3) mendapatkan stigma dari orang lain terkait COVID-19, (4) merupakan penyintas COVID-19 pertama di daerah tertentu di Indonesia, dan (5) bersedia menjadi partisipan dalam penelitian ini. Kriteria inklusi nomor (1), (2), (3), dan (5) merupakan kriteria dasar pada partisipan penyintas COVID-19 yang mengalami stigma. Sedangkan kriteria nomor (4) dipilih untuk memperbesar kemungkinan intensitas stigma yang didapatkan. Sedangkan kriteria eksklusi partisipan adalah: (1) tidak dapat menggunakan gadget (karena pengambilan data dilakukan secara daring), dan (2) tidak dapat berbahasa Indonesia dengan baik (karena akan memengaruhi kualitas pemaknaan peneliti). Proses pencarian partisipan dilakukan melalui media massa online dan mengumpulkan sebanyak 5 calon partisipan yang pernah diliput oleh media massa. Pemilihan penggunaan media massa untuk pencarian partisipan dilakukan dengan mempertimbangkan adanya situasi pandemi yang membatasi mobilitas. Lalu peneliti menyeleksi partisipan berdasarkan kriteria yang telah ditentukan dan mendapatkan 1 partisipan. Adapun penentuan jumlah partisipan dilakukan berdasarkan Starks dan Trinidad (2007).

\section{Pengumpulan dan analisis data}

Partisipan dihubungi oleh peneliti dan menyetujui informed consent, sehingga dilakukan melalui wawancara semi-terstruktur secara online selama satu kali pertemuan dengan durasi +3 jam. Pengambilan data dilakukan secara online karena situasi pandemi dan kendala jarak lokasi yang membatasi pertemuan langsung dengan partisipan. Triangulasi sumber data dilakukan berdasarkan koherensi jawaban wawancara partisipan serta pernyataan partisipan di media massa dan media sosial. Penyusunan outline wawancara dilakukan berdasarkan literatur yang relevan. Pertanyaan utama dalam wawancara adalah: (1) "Bagaimana pengalaman menjadi penyintas COVID-19?", (2) "Kesulitan apa yang dialami selama menjadi penyintas COVID19?", (3) Apa yang Anda lakukan selama menemui kesulitan tersebut?", dan (4) "Bagaimana pengalaman selama menghadapi stigma?" serta berbagai pertanyaan pengembangan lain. Pertanyaan-pertanyaan disampaikan berdasarkan kronologi pengalaman, sehingga tidak disampaikan secara terang-terangan, termasuk yang berkaitan dengan stigma. Setelah wawancara, peneliti segera membuat transkrip wawancara dan melakukan analisis. Analisis data melalui 3 tahap, yaitu: (1) membaca data berulang kali, (2) pencatatan awal, dan (3) mengangkat tema yang muncul (Smith dkk., 2009). 


\section{HASIL}

Penelitian ini mengeksplorasi pengalaman psikologis dan strategi coping yang dilakukan oleh partisipan penyintas COVID-19, termasuk yang berkaitan dengan stigma terhadapnya. Partisipan penelitian merupakan laki-laki berusia 29 tahun, belum menikah, bekerja sebagai pegawai negeri, dan merupakan pasien positif COVID-19 pertama di suatu daerah di Indonesia. Hasil penelitian memunculkan tiga tema utama, yakni: (1) tantangan sebagai penyintas COVID-19, (2) stigma terhadap penyintas COVID-19, dan (3) strategi coping penyintas COVID-19.

\section{Tema 1: Tantangan sebagai penyintas COVID-19}

Partisipan mengalami berbagai permasalahan dan tantangan sebagai penyintas COVID-19. Tantangan terbesar ada selama menjalani perawatan isolasi di rumah sakit. Sebagai pasien positif COVID-19 pertama di daerahnya, partisipan banyak menghadapi permasalahan yang berkaitan dengan penanganan COVID-19. Prosedur perawatan belum berlangsung secara maksimal, karena keterbatasan informasi dan penelitian mengenai penanganan COVID-19, ketidaksiapan manajemen dan fasilitas rumah sakit, maupun kebijakan yang tidak mendukung efisiensi penanganan COVID-19, terutama pada proses swab. Selain itu, partisipan juga tidak siap untuk menjadi pasien positif COVID-19 karena tidak pernah menduga sebelumnya. Selain itu, COVID-19 merupakan jenis penyakit baru yang memiliki kesan negatif dan dipenuhi dengan ketidakpastian atas kemungkinan kesembuhan. Di samping itu, partisipan juga telah mendapatkan tekanan sejak awal dari perlakuan tenaga medis terhadapnya.

Selama menjalani perawatan isolasi, partisipan merasakan emosi negatif yang intens, dalam bentuk kekesalan, kekhawatiran, kejenuhan, kesepian, kekecewaan, dan kehilangan semangat, dengan perasaan kesal yang mendominasi. Partisipan mengalami kesulitan dalam meregulasi emosi negatif di masa awal hingga pertengahan isolasi. Ada banyak hal yang membuat partisipan merasakan emosi negatif tersebut, terutama karena adanya ekspektasi atau keinginan yang tidak sesuai dengan kenyataan, sehingga partisipan menjadi sulit menoleransi hal yang tidak pasti. Hal tersebut membuat partisipan membutuhkan waktu panjang untuk menerima kondisinya saat itu. Selain itu, partisipan juga mendapatkan tekanan dari media massa karena statusnya sebagai pasien COVID-19 pertama di daerahnya, serta karena banyaknya informasi tidak akurat mengenai COVID-19 yang beredar.

Tantangan bagi partisipan juga masih berlangsung selama masa akhir perawatan hingga setelah dinyatakan sembuh. Akan tetapi, partisipan menghadapi tantangan di masa itu dengan lebih tenang, sehingga permasalahan tersebut tidak menjadi tekanan yang terlalu besar bagi partisipan. Adapun bentuk permasalahan baru yang ditemui partisipan adalah stigma dari orang lain terhadap dirinya. Secara keseluruhan, bentuk tantangan yang dihadapi oleh partisipan berasal dari eksternal dan internal, berdasarkan Tabel 1 berikut ini.

Tabel 1.

Tema 1: Tantangan sebagai Penyintas COVID-19

Tantangan sebagai Penyintas COVID-19

\begin{tabular}{|c|c|}
\hline Subtema & Kutipan \\
\hline Eksternal & \\
\hline 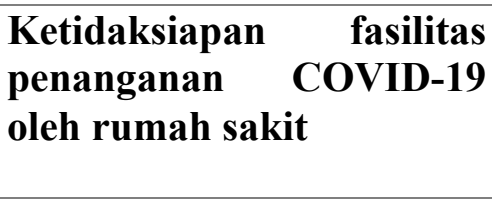 & $\begin{array}{l}\text { "Tapi jujur aku kaget sih di dalem rumah sakit itu, } \\
\text { maksudnya kayak ini adalah rumah sakit rujukan pemerintah } \\
\text { yang ditunjuk untuk kota P pada waktu itu, dan seperti ini } \\
\text { fasilitasnya, bahkan menurutku minimal rumah sakit itu }\end{array}$ \\
\hline
\end{tabular}


bersih gitu kan."

Ketidakakuratan
informasi "Selama ini diberitakannya kok bagus-bagus aja? Gitu.
$\begin{aligned} & \text { COVID-19 yang beredar } \\ & \text { di media }\end{aligned}$

Keterbatasan informasi "Terus dokter kenapa ngga pada ngedukasi masyarakat
mengenai COVID-19 kalau ternyata dokter tau kalau gejala di tiap orang itu berbeda?"

Ketidakpastian hasil swab "Bahwa kita tuh menjumpai satu permasalahan besar, yaitu (lama) lamanya hasil swab itu keluar. ... pada waktu itu hasilnya keluarnya lama banget, jadi lama banget itu karena melalui berbagai proses gitu. ... prosesnya itu bertele-tele banget menurut aku,"

\begin{tabular}{ll}
\hline Stigma dari orang lain & "Menghadapi penerimaan dari masyarakat itu ternyata berat \\
& loh."
\end{tabular}

Internal

Ketidaksiapan diri untuk "Ini bener-bener kejadian yang aku sama sekali nggak menjadi PDP dan pasien kepikiran bahwa aku akan seperti ini jadinya." positif COVID-19

Persepsi negatif tentang "Selama ini kan kita ngeliat banyak banget korban-korban COVID-19 berjatuhan, visualisasi yang disampaikan di media di Indonesia kan gambaran COVID di Itali kan, pada waktu itu, di Itali dan di Wuhan, mereka kan selalu ngangkat gambargambar, video-video dari negara-negara itu, dimana mayat itu bergelimpang di jalan, terus rumah sakit penuh, segala macem."

\begin{tabular}{|c|c|}
\hline $\begin{array}{l}\text { Kekhawatiran } \\
\text { ketidakpastian } \\
\text { kesembuhan }\end{array}$ & $\begin{array}{l}\text { "Aduh, gimana ini kalau misalnya kena, obatnya gimana, apa } \\
\text { saya akan meninggal juga apa gimana?" }\end{array}$ \\
\hline $\begin{array}{l}\text { Ekspektasi untuk segera } \\
\text { sembuh }\end{array}$ & $\begin{array}{l}\text { "Jadi aku cuma bisa ngelihat dari jauh bahwa kapan ya } \\
\text { giliran aku tiba untuk pulang? Kayak gitu loh. Aku juga } \\
\text { pengen pulang kayak gitu kan." }\end{array}$ \\
\hline $\begin{array}{l}\text { Penerimaan } \\
\text { kondisi }\end{array}$ & $\begin{array}{l}\text { "... Ngeliat sesuatu tuh dengan kekesalan dengan ah kok kok, } \\
\text { birokrasi kayak gini banget sih, kesel keseeeel kesel kesel ..." }\end{array}$ \\
\hline
\end{tabular}

Tema 2: Stigma terhadap penyintas COVID-19

Stigma menjadi salah satu tantangan tersendiri bagi partisipan, sejak awal proses perawatan hingga setelah dinyatakan sembuh. Stigma yang dialami partisipan berupa stereotip (stereotype) dan prasangka (prejudice).

Stigma di awal proses perawatan dilakukan oleh tenaga medis, sedangkan stigma pascakesembuhan dilakukan oleh orang di sekitar dan teman partisipan. Stereotip yang dialami partisipan berupa anggapan masyarakat sekitar bahwa ia masih dapat menularkan virus 
COVID-19. Partisipan menyampaikan, "Nah ketika ngobrol-ngobrol, aku nawarkan kayak cemilan, ya biasa lah, ada tamu, kita menyajikan cemilan dan minuman, dia tu sama sekali ngga mau makan, ngga mau makan cemilan itu dan minuman yang aku tuangkan istilahnya. Karena pada waktu itu kan aku ngeliatin gerak-geriknya kok aneh gitu kan. Terus aku tanya, "Kenapa? Kenapa? Kok nggamau diminum-minum sih?" Kayak gitu kan. "Takut ya?" Aku bilang kayak gitu. Terus dia bilang, "Iya, masih takut."." Sedangkan prasangka yang dihadapi partisipan berupa pemotretan dirinya saat akan dirujuk ke rumah sakit rujukan COVID-19 serta keengganan teman partisipan untuk mencicipi jamuan makan dari rumah partisipan. Meskipun demikian, partisipan juga menemukan banyak respon positif dari teman-temannya serta tidak mengalami stigma dalam bentuk diskriminasi. Adapun keterangan mengenai stigma yang dihadapi partisipan berada di Tabel 2 berikut ini.

Tabel 2.

Tema 2: Stigma terhadap Penyintas COVID-19

Stigma terhadap Penyintas COVID-19

\begin{tabular}{|c|c|}
\hline Subtema & Kutipan \\
\hline $\begin{array}{l}\text { Pengambilan gambar oleh } \\
\text { tenaga medis }\end{array}$ & $\begin{array}{l}\text { "Kayak mereka ngambil gambar-gambar aku, segala macem, } \\
\text { padahal yang ngambil gambar juga para perawat di sana, } \\
\text { gitu kan, menurut aku secara etika harusnya tidak seperti } \\
\text { itu." }\end{array}$ \\
\hline $\begin{array}{lr}\text { Kewaspadaan } & \text { lingkungan } \\
\text { terhadap } & \text { penyintas } \\
\text { COVID-19 } & \end{array}$ & $\begin{array}{l}\text { "Eh itu kan pernah kena cov-pernah kena corona, hati-hati } \\
\text { loh, segala macem." }\end{array}$ \\
\hline $\begin{array}{l}\text { Rasa takut untuk } \\
\text { menggunakan barang } \\
\text { penyintas COVID-19 }\end{array}$ & $\begin{array}{l}\text { "Kenapa? Kenapa? Kok nggamau diminum-minum sih?" } \\
\text { Kayak gitu kan. "Takutya?" Aku bilang kayak gitu. Terus dia } \\
\text { bilang, "Iya, masih takut.", }\end{array}$ \\
\hline
\end{tabular}

\section{Tema 3: Strategi coping penyintas COVID-19}

Partisipan melakukan berbagai strategi coping sebagai penyintas COVID-19. Bentuk coping partisipan beragam dan menunjukkan adanya perubahan menjadi strategi coping yang lebih adaptif. Sejak awal, partisipan menghadapi stresor dari adanya ketidakpastian dan ketidaksesuaian kualitas penanganan COVID-19, yang mana disebabkan adanya permasalahan yang kompleks di baliknya. Pada awalnya, partisipan berusaha menyelesaikan permasalahan secara langsung, seperti membersihkan ruangan isolasi saat mengetahui keadaan gedung isolasi yang tidak siap, mencari informasi yang dibutuhkan, dsb. Namun, kompleksitas permasalahan membuat partisipan tidak dapat ikut menyelesaikan permasalahan tersebut secara langsung, karena permasalahan tersebut berkaitan dengan kebijakan nasional, manajemen dan fasilitas rumah sakit, maupun media massa. Hal ini membuat partisipan merasa kesal dan terkadang melontarkan kekesalannya pada orang lain. Meskipun begitu, partisipan cenderung tidak melakukan apapun untuk mengurangi tingkat kekesalannya, sehingga rasa kesal tersebut semakin meningkat secara kumulatif seiring waktu. Rasa kesal muncul karena adanya kontradiksi antara keinginan besar untuk menyelesaikan masalah sekaligus rasa tidak berdaya untuk melakukannya.

Sehingga, partisipan pernah berada di titik terpuruknya selama menjalani perawatan, kemudian memilih untuk menulis sebagai cara untuk melepaskan emosi negatifnya dan menyampaikan permasalahan yang ia hadapi selama menjalani perawatan kepada Presiden. Partisipan memiliki harapan besar agar surat tersebut dapat memperbaiki sistem penanganan COVID-19 di Indonesia, namun di sisi lain juga berarti bahwa partisipan akan menjadi sangat 
kecewa ketika surat tersebut tidak memberikan dampak. Partisipan kemudian meminta saran dari ibu dan temannya, hingga akhirnya menyadari bahwa ia telah melakukan perannya dengan baik dan sesuai dengan batasannya. Partisipan menjadi lebih tenang dengan tidak menuntut dirinya lebih jauh untuk mengubah banyak hal.

Selain itu, partisipan juga menerima layanan konseling dari psikolog. Layanan tersebut membantu partisipan untuk mengelola emosi negatifnya dan menerima kondisi dirinya secara lebih realistis. Partisipan juga mulai menemukan makna yang berbeda dari proses isolasi yang sedang ia jalani, yakni sebagai bentuk cuti pekerjaan sehingga dapat ia gunakan sebagai kesempatan untuk mengeksplorasi minatnya terhadap seni selama ini. Partisipan melakukan banyak hal untuk mengeksplorasi diri dengan sistem yang terjadwal. Partisipan pun menganggap kamar isolasinya sebagai studio untuk berkreasi dan beraktivitas. Selain itu, partisipan juga mengurangi intensitas penggunaan gadget untuk membatasi arus informasi yang masuk. Di samping itu, partisipan juga proaktif untuk membangun interaksi dengan orangorang di rumah sakit, terutama perawat, serta berusaha membangun kedekatan dengan Tuhan. Adanya aktivitas mandiri dan interaksi bersama pihak lain membuat partisipan merasa lebih bersemangat dan bahagia hingga saat kepulangan.

Partisipan menunjukkan cara coping yang berbeda dalam menghadapi stigma. Pada masa awal perawatan, partisipan belum menemukan cara yang tepat dalam menghadapi respon stigma dari orang lain. Partisipan mengalami distorsi kognitif dengan tidak dapat berpikir jernih ataupun melakukan sesuatu saat awal mendapatkan stigma. Partisipan mengatakan, " $A k u$ nggabisa ngelakuin apa-apa. Jadi aku pribadi bener-bener terdiam gitu loh. Secara teori aku tau, mungkin aku bisa tangan kayak gini, "Eh jangan dong, jangan, jangan foto aku." Tapi, ketika aku menghadapi situasi itu, aku nggabisa berpikir apa-apa, karena aku mikir kan aku bukan artis, bukan public figure, bukan apa kan, jadi aku tidak pernah berada di satu kejadian di mana orang tu bener-bener perhatian tu langsung ke aku gitu."

Sedangkan saat pasca-kepulangan, strategi coping yang partisipan gunakan adalah dengan menjelaskan kondisinya yang telah sembuh serta membangun batasan tanggung jawab terhadap sudut pandang orang lain padanya. Partisipan menganggap bahwa pandangan dan sikap orang lain adalah suatu hal yang tidak dapat ia kontrol, sehingga ia tidak ingin membebani dirinya dengan merasa bertanggung jawab secara berlebih atas pilihan orang lain dalam memandang dirinya. Partisipan mengatakan, "Ada hal-hal yang nggak bisa kita kontrol gitu loh. Yang nggak bisa kita kontrol itu adalah pikiran orang lain. Ya kan? Respon orang lain. Itu kan hal di luar, istilahnya hal di luar teritorial kita gitu kan. Kita bisa memberikan penjelasan, pemahaman, gitu loh. Tapi memang itu kan di luar, di luar teritori kita gitu kan. Dia yang punya hak atas pemikiran dia sendiri gitu kan. Dan aku pada waktu itu, berpikir kayak gini, kalau orang lain takut terhadap aku, itu masalah dia, bukan masalah aku."

Selain itu, partisipan juga aktif membagikan pengalaman menjadi penyintas COVID-19 dan membantu penyintas COVID-19 lainnya dalam meningkatkan optimisme mereka. Partisipan memaknai pengalaman menjadi penyintas COVID-19 sebagai kesempatan untuk menyuarakan pengalaman penyintas COVID-19 lainnya. Partisipan mengatakan, "Kenapa aku yang kena covid, karena aku harus memainkan peran aku sebagai orang yang pernah kuliah, orang yang pernah dididik gitu kan di bangku perguruan tinggi, aku harus memainkan bagian aku gitu loh, untuk memberikan masukan pada pemerintah, untuk mewakili suara orang-orang yang tidak bisa bersuara di sana, orang yang powerless, orang yang juga tidak mengenyam pendidikan yang tinggi, gitu kan, aku harus mewakili mereka, gitu loh, untuk menyuarakan pendapat, menyuarakan aspirasi kami. Jadi ada hikmah yang aku petik sih dari COVID-19 ini dan itu bener-bener mengubah mengubah hidupku." Secara keseluruhan, strategi coping yang 32

Rahma Ayuningtyas Fachrunisa - Strategi coping pada penyintas covid-19 
dilakukan oleh partisipan mengalami penyesuaian menjadi lebih adaptif selama menjadi penyintas COVID-19. Keterangan mengenai strategi coping partisipan berada dalam Tabel 3.

Tabel 3.

Tema 3: Strategi Coping Penyintas COVID-19

Strategi Coping Penyintas COVID-19

\begin{tabular}{ll}
\hline \multicolumn{1}{c}{ Subtema } & \multicolumn{1}{c}{ Kutipan } \\
\hline Maladaptif & \\
\hline Membiarkan emosi negatif & "Ngga ada sih, ngga ada yang aku, aku pada waktu itu tidak \\
dalam waktu panjang & sama sekali berpikir untuk meredakan kekesalanku. Ngga \\
& ada. Aku bener-bener pada waktu itu ya aku kesel kesel kesel \\
& kesel kesel kesel kesel kayak gitu. Jadi, ngga ada yang aku \\
& lakukan sih. Bener-bener aku bawa aja. Aku bawa sampe \\
& tidur, aku bangun aku kesel lagi." \\
\hline
\end{tabular}

Adaptif

Mencari informasi terkait "“Dok, emangnya hasil swab saya yang pertama gimana? COVID-19 Kok udah swab ketiga aja nih? Kan aku kepo gitu kan."

Mencari dukungan dari "Jadi, itu titik terendah aku itu ngerasa bahwa apa lagi nih, orang lain (keluarga, coba aku sampe bilang ke ibuku coba kasih ide apa lagi apa teman, dan perawat) lagi. Apa lagi yang bisa kita perjuangkan?"

Menerima layanan "Pihak yang juga membantu adalah psikolog."

psikolog

Menulis "Makanya pada waktu itu, aku ada sampe di satu titik di mana kayanya aku harus menulis sesuatu gitu loh, untuk stress release aku kayak gitu, ... kayanya aku harus memberitahu bahwa situasinya seperti ini."

Memaknai proses isolasi "Aku tu tidak sedang diisolasi, tapi aku tu sedang dikasih cuti sama Allah, gitu loh. Nah aku tuh dibebastugaskan dari semua kerjaan-kerjaan kantor aku, istilahnya, aku dikasih cuti loh, cuti yang aku nggatau sampe kapan ini panjang cutinya sampe kapan gitu. Jadi saatnya, ini adalah saatnya aku mengisi hari-hariku dengan hal-hal yang selama ini tuh ngga pernah bisa aku lakuin."

Beraktivitas untuk "Aku tuh selalu pengen belajar untuk bikin sketsa, belajar mengembangkan minat bikin gambar ilustrasi, gitu. Aku ngga pernah punya waktu, dan keterampilan misalkan belajar ngedit video, belajar ngedit-ngedit foto dengan software-software terkini, gitu. ... jadi aku ngerasa bahwa this is the moment gitu loh. Aku bisa ngelakuin itu sekarang, aku bisa ngisi hari-hari aku."

\begin{tabular}{ll}
\hline $\begin{array}{l}\text { Mengurangi intensitas } \\
\text { penggunaan gadget untuk } \\
\text { mengurangi arus ketika momen-momen itu tu aku menjauhkan diri dari } \\
\text { informasi yang masuk }\end{array}$ & $\begin{array}{l}\text { bener me time gitu." } \\
\text { bendekatkan diri pada }\end{array}$ \\
$\begin{array}{l}\text { Tuhan } \\
\text { "Jadi perjalanan menjalani covid itu menurutku perjalanan } \\
\text { spiritual yah menurutku, karena banyak sekali kan momen } \\
\text { untuk berkontemplasi, momen untuk berpikir, momen untuk } \\
\text { mengenal diri sendiri, momen untuk lebih dekat dengan } \\
\text { Allah," }\end{array}$ \\
\hline
\end{tabular}




\begin{abstract}
Mengetahui keterbatasan "Di situ baru aku bener-bener bisa naik lagi semangatku diri

bahwa oke itu bagian aku. Cuma itu yang bisa aku lakukan. Gitu. Aku ngga punya kuasa lebih jauh, aku ngga punya power lebih, lebih, untuk melakukan itu. Aku harus tau limit aku sampai di mana. Itu sih yang menjadi turning point aku sih."
\end{abstract}

\begin{tabular}{l} 
Dalam menghadapi stigma: \\
\hline Menjelaskan kondisi diri \\
untuk mengurangi \\
kesalahpahaman
\end{tabular}

"Padahal aku sudah meluruskan bahwa aku tuh sudah sembuh lho, aku sudah sembuh. Bahkan aku nunjukin di dalem handphoneku kan aku foto hasil surat keterangan sehat dari dinas kesehatan kan bahwa aku sudah dinyatakan sembuh."

\begin{tabular}{|c|c|}
\hline $\begin{array}{l}\text { Melepaskan diri dari } \\
\text { perasaan bertanggung } \\
\text { jawab atas permasalahan } \\
\text { orang lain berupa } \\
\text { pandangan } \\
\text { terhadap dirinya }\end{array}$ & $\begin{array}{l}\text { "Ada hal-hal yang nggak bisa kita kontrol gitu loh. Yang } \\
\text { nggak bisa kita kontrol itu adalah pikiran orang lain. Ya kan? } \\
\text { Respon orang lain. ... kalau orang lain takut terhadap aku, } \\
\text { itu masalah dia, bukan masalah aku." }\end{array}$ \\
\hline $\begin{array}{l}\text { Berbagi pengalaman dan } \\
\text { pengetahuan terkait } \\
\text { COVID-19 }\end{array}$ & $\begin{array}{l}\text { "Ya sebenernya membagikan cerita, cerita ini juga, sama gitu } \\
\text { loh. Membagikan semangatjuga. ... Makanya aku selalu aktif } \\
\text { di media sosial karena menurutku itu adalah platform di } \\
\text { mana orang tuh bisa mendapatkan ee apa ya, pembelajaran } \\
\text { dari apa yang aku lewati pada waktu itu. Gituh." }\end{array}$ \\
\hline
\end{tabular}

\title{
DISKUSI
}

Penelitian ini mengeksplorasi strategi coping pada penyintas COVID-19 yang mengalami stigma dalam bentuk stereotip dan prasangka. Meskipun partisipan dalam penelitian ini tidak menghadapi semua jenis stigma publik terhadap penyintas COVID-19, namun penelitian ini telah mengangkat dinamika psikologis pasien, tantangan selama perawatan, dan strategi coping yang dilakukan penyintas COVID-19 dalam menghadapi berbagai stresor, termasuk yang disebabkan oleh stigma. Pettit (2008) menjelaskan bahwa isu yang perlu dihadapi pasien tidak hanya isu kesehatan, namun juga isu stigma sosial yang seringkali diasosiasikan pada pasien. Beberapa penelitian telah dilakukan untuk mengetahui dampak stigma terhadap individu dengan isu kesehatan tertentu, seperti HIV-AIDS (Hasibuan, Aryani \& Simajuntak, 2019) dan gangguan mental (Michaels, Lopez, Rusch, \& Corrigan, 2012). Pettit (2008) mencoba menelusuri sejarah keterkaitan antara stigma dan penyakit hingga akhirnya menemukan bahwa permasalahan tersebut telah ada sejak tahun 1900-an sejak adanya penyebaran penyakit tertentu dari individu ke masyarakat.

Permasalahan stigma publik yang dihadapi oleh partisipan berupa stereotip atau keyakinan negatif mengenai individu atau kelompok dengan karakteristik tertentu; dan prasangka atau sikap setuju terhadap keyakinan terhadap individu atau kelompok dengan karakteristik khusus tertentu, dan/atau reaksi emosi negatif yang meliputi marah dan ketakutan. Michaels dkk. (2012) menjelaskan bahwa stigma publik merupakan bentuk keyakinan atau anggapan tertentu dalam masyarakat yang ditujukan pada individu dengan karakteristik tertentu. Dwinantoaji, dkk.. (2020) menyebutkan bahwa stigma terhadap COVID-19 disebabkan oleh angka penyebaran infeksi yang tinggi, keterbatasan informasi, dan informasi yang salah terkait COVID-19. Stigma ini dapat ditujukan pada pasien positif COVID-19, orang yang diduga 
terkena COVID-19, pasien COVID-19 yang telah sembuh, hingga fasilitas kesehatan dan tenaga medis yang menangani COVID-19 (Bhattacharya dkk, 2020; Mahmud \& Islam, 2020). Sedangkan partisipan tidak mengalami diskriminasi dari masyarakat karena lebih banyak menjalani perawatan di rumah sakit, mendapatkan dukungan keluarga, teman, dan lingkungan kerja, dan merupakan perantau yang tidak lama tinggal di lingkungan asal pasca-perawatan.

Michaels dkk. (2012) juga menjelaskan stigma terkait isu kesehatan berupa stigma diri (selfstigma). Stigma diri merupakan proses internalisasi stigma publik dan secara terus-menerus menyetujui stigma publik yang ditujukan pada dirinya. Stigma publik yang terinternalisasi pada individu dapat memengaruhi kepercayaan diri (self-esteem) dan kehidupan sosial. Partisipan juga menunjukkan kondisi kurang percaya diri setelah kepulangan, namun proses internalisasi stigma tersebut tidak terlalu memengaruhi kehidupan partisipan karena partisipan bersedia untuk asertif dalam menyampaikan kesembuhannya dan mendapatkan dukungan dari keluarga. Selain itu, intensitas stigma publik yang dialami partisipan secara langsung juga tergolong tidak tinggi.

Adapun strategi coping partisipan dalam menghadapi stigma menunjukkan adanya perubahan, yakni bersifat maladaptif saat pertama kali menghadapinya dalam bentuk membiarkan emosi negatif yang muncul dalam jangka waktu panjang, dan lebih adaptif setelah kepulangan dengan cara mengkomunikasikan kondisi diri, memberikan batasan tanggung jawab pada diri sendiri, serta berbagi pengalaman sebagai penyintas COVID-19. Strategi coping yang dilakukan, terutama terhadap stigma publik, berubah sesuai dengan kesiapan partisipan menghadapi hal tidak terduga beserta ketidakpastiannya. Riyono (2020) menggambarkan ketidakpastian (uncertainty) sebagai suatu kondisi yang memiliki banyak kemungkinan yang belum jelas baik-buruknya dan belum tentu akan terjadi. Pada awalnya, partisipan mengkritik permasalahan namun tidak dapat melakukan apapun dalam menghadapi prasangka padanya. Setelah kepulangan, partisipan dapat proaktif dalam menjelaskan kondisinya dan menoleransi berbagai macam kemungkinan respon orang lain terhadapnya dengan tidak membebani diri atas pandangan orang lain terhadapnya.

Penelitian ini memberikan penekanan bahwa adanya perubahan strategi coping terhadap stigma pada partisipan dipengaruhi oleh bentuk strategi coping pasien terhadap permasalahan lain selama menjalani penanganan COVID-19. Pada awalnya, partisipan menggunakan problem-focused coping di masa awal perawatan, namun kemudian partisipan menemui berbagai permasalahan yang tidak dapat ia kontrol sehingga strategi coping tersebut tidak memberikan dampak positif padanya, dan memunculkan emosi negatif yang terakumulasi secara berkepanjangan, seperti dalam bentuk kekhawatiran dan rasa kesal. Yanuardi (2017) menyebutkan berbagai penelitian yang menunjukkan keterkaitan antara intoleransi pada ketidakpastian (intolerance of uncertainty) terhadap emosi negatif berupa khawatir (worry) dan cemas (anxiety). Semakin besar ketidakmampuan individu untuk menerima ketidakpastian, maka semakin besar risiko mengalami kekhawatiran dan kecemasan yang intens. Ketidakpastian (uncertainty) sebagai stresor bagi pasien ini juga ditunjukkan dalam penelitian oleh Lie, Larsen \& Hauken, (2018).

Kemudian, partisipan mulai mengembangkan strategi coping selama menjalani perawatan COVID-19 secara lebih adaptif sejak menerima layanan psikologis. Setelah mendapatkan layanan tersebut, partisipan mulai mengembangkan meaning-focused coping. Biggs, Brough, dan Drummond (2017) menjelaskan kembali meaning-focused coping dari Lazarus dan Folkman sebagai strategi coping yang biasa dilakukan ketika stresor dianggap berlebihan dan tidak dapat dikontrol, kemudian ditandai dengan melibatkan nilai-nilai pribadi dalam menghadapi stresor, penyusunan kembali prioritas dalam hidup, pengembangan makna positif 
dari hal yang ditemui, dan pencarian manfaat dari stresor, sehingga dapat memunculkan emosi positif terhadap sumber stres. Emosi positif tersebut juga mendukung partisipan untuk mempertahankan penggunaan meaning-focused coping dalam jangka panjang. Adanya pemaknaan positif oleh partisipan terhadap proses perawatan maupun fase setelahnya juga membantu pasien untuk menoleransi ketidakpastian yang dihadapi sehingga juga menurunkan emosi negatif yang sebelumnya dialami oleh partisipan.

Selain itu, partisipan juga melakukan strategi coping yang adaptif lainnya, seperti dengan melakukan aktivitas menulis saat partisipan merasa terpuruk. Murnahan (2010) menyebutkan bahwa aktivitas menulis dapat menjadi bentuk manajemen stres dan mengurangi perasaan stres, dapat berupa tulisan diari, jurnal harian, surat atau e-mail, dan blog. Selain itu, partisipan juga meningkatkan kualitas hubungan dengan Tuhan dan secara aktif membangun interaksi sosial dengan keluarga, teman, dan tenaga medis sehingga mendapatkan dukungan sosial selama proses perawatan. Nursalam, Sukartini, Mafula dan Efendi (2020) menyebutkan bahwa pasien COVID-19 yang tidak mendapatkan dukungan sosial berisiko mengalami permasalahan psikologis yang lebih serius.

Penelitian ini menunjukkan bahwa perubahan strategi coping penyintas COVID-19 menjadi lebih adaptif membutuhkan proses yang tidak instan dan cenderung membutuhkan peran pihak lain dalam mendampingi pasien menghadapi dampak psikologis fenomena COVID-19. Sehingga, penelitian ini memberikan implikasi bahwa pengembangan strategi coping yang adaptif pada penyintas COVID-19 tidak dapat dilepaskan dari upaya pendampingan psikologis selama penanganan, sehingga bersifat jangka panjang. Pendampingan psikologis tersebut perlu memperhatikan pengembangan strategi coping yang tepat terhadap salah satu stresor utama bagi pasien, yakni ketidakpastian selama menjalani proses penanganan. Riyono (2020) menjelaskan bahwa cara yang tepat dalam menyikapi ketidakpastian adalah dengan menumbuhkan harapan (hope), bukan ekspektasi yang tidak menoleransi adanya kemungkinan lain di luar yang diinginkan. Harapan tersebut merupakan keyakinan bahwa sesuatu yang baik akan muncul di balik suatu ketidakpastian, sehingga dapat mengakomodasi ketidakpastian yang ada. Tingkat harapan yang tinggi dapat memaksimalkan tingkat motivasi pasien, sehingga pasien dapat memiliki motivasi yang optimal (psychological state of optimum opportunity).

Adanya penelitian terhadap penyintas COVID-19 pertama di suatu daerah di Indonesia ini dapat memberikan gambaran dinamika psikologis dan tantangan yang dialami oleh penyintas COVID-19 di Indonesia. Meskipun demikian, jumlah partisipan dalam penelitian ini terbatas pada satu orang, sedangkan masyarakat Indonesia memiliki beragam latar belakang geografis, status sosial ekonomi, budaya, maupun pendidikan. Sehingga, studi selanjutnya dapat melibatkan partisipan yang lebih beragam untuk mengeksplorasi pengalaman psikologis dan strategi coping pada penyintas-penyintas COVID-19 yang mengalami stigma, termasuk stigma dalam bentuk diskriminasi (yang juga merupakan bentuk dari stigma publik) di Indonesia. Selain itu, studi selanjutnya juga perlu mengakomodasi berbagai latar belakang penyintas COVID-19, dalam hal usia, jenis kelamin, pendidikan, tingkat ekonomi, dan tingkat keparahan penyakit yang disebabkan COVID-19. Studi selanjutnya pun juga dapat dilakukan dengan tidak hanya mengikutsertakan penyintas COVID-19 pertama di daerah tertentu di Indonesia, sehingga hasil studi dapat menggambarkan konteks situasi yang lebih beragam.

\section{KESIMPULAN}

Penelitian ini memberikan referensi strategi coping yang adaptif bagi penyintas COVID-19 yang mengalami stigma, termasuk pengalaman psikologis yang ada secara mendalam. Selain itu, penelitian ini juga memberikan saran pengembangan strategi coping pada penyintas 36

Rahma Ayuningtyas Fachrunisa - Strategi coping pada penyintas covid-19 
COVID-19, yakni dengan mempertimbangkan permasalahan mendasar yang dihadapi. Sehingga, penelitian ini dapat digunakan sebagai pertimbangan pengembangan kebijakan nasional maupun institusi kesehatan dalam meningkatkan efektivitas penanganan COVID-19 di Indonesia.

\section{DAFTAR PUSTAKA}

Bhattacharya, P., Banerjee, D., \& Rao, T. S. (2020). The "untold" side of COVID-19: Social Stigma and Its Consequences in India. Indian Journal of Psychological Medicine, 42, 15. https://doi.org/DOI: 10.1177/0253717620935578

Biggs, A., Brough, P., \& Drummond, S. (2017). Lazarus and Folkmans psychological stress and coping theory. In C. L. Cooper \& J. C. Quick (Eds.), The Handbook of Stress and Health A guide to Research and Practice (pp. 351-364). John Wiley \& Sons Ltd.

Cacciapaglia, G., Con, C., \& Sannino, F. (2020). Second wave COVID-19 pandemics in Europe a temporal playbook. Scientific Reports, 10(15514), 1-8. https://doi.org/10.1038/s41598020-72611-5

Dwinantoaji, H., \& W., S. D. (2020). Human security, social stigma, and global health: the COVID-19 pandemic in Indonesia. Journal of the Medical Sciences, 52(3), 158-165.

Guo, J., Feng, X.L., Wang, X.H., Van Ijzendoorn, M. H. (2020). Coping with COVID-19: Exposure to COVID-19 and negative impact on livelihood predict elevated mental health problems in chinese adults. International Journal of Environmental Research and Public Health, 17(3857), 1-18. https:// doi:10.3390/ijerph17113857

Hasibuan, E. K., Aryani, N., \& Simajuntak, G. V. (2019). Stigma dan diskriminasi serta strategi koping pada orang dengan HIV dan AIDS (ODHA) di Kota Medan, Sumatera Utara. Holistik Jurnal Kesehatan, 13(4), 396-401.

Lie, N.-E. K., Larsen, T. M. B., \& Hauken, M. A. (2018). Coping with changes and uncertainty: A qualitative study of young adult cancer patients' challenges and coping strategies during treatment. European Journal of Cancer Care, 17(6), 1-10. https://doi.org/DOI: $10.1111 /$ ecc. 12743

Mahmud, A., \& Islam, M. R. (2020). Social stigma as a barrier to COVID-19 responses to community well-being in Bangladesh. International Journal of Community Well-Being. https://doi.org/10.1007/s42413-020-00071-w

Michaels, P. J., Lopez, M., Rusch, N., \& Corrigan, P. W. (2012). Constructs and concepts comprising the stigma of mental illness. Psychology, Society \& Education, 4(2), 183-194.

Moleong, L. J. (2012). Metodologi Penelitian Kualitatif. PT Remaja Rosdakarya.

Murnahan, B. (2010). Stress and anxiety reduction due to writing diaries journals e-mail and webblogs. Senior Honors Thesis, 230.

Nursalam, N., Sukartini, T., Mafula, D., \& Efendi, F. (2020). Risk Factors for Psychological Impact and Social Stigma among People Facing COVID-19: A Systematic Review. Systematic Reviews in Pharmacy, 11(5), 1022-1028.

Pettit, M. L. (2008). Disease and stigma: A review of literature. The Health Educator, 40(2), $70-76$.

Ramaci, T., Barattucci, M., Ledda, C., \& Rapisarda, V. (2020). [Ramaci] Social stigma during 
COVID-19 and its impact on HCWs outcomes. Sustainability, 12(3834), 1-13. https://doi.org/10.1007/s42413-020-00071-w

Riyono, B. (2020). Motivasi dan Kepribadian: Perspektif Islam tentang Dinamika Jiwa dan Perilaku Manusia (2nd ed.). Al-Mawardi.

Satuan Tugas Penanganan COVID-19. (2020). Peta Sebaran. Data COVID-19. https://covid19.go.id/peta-sebaran

Setiati, S., \& Azwar, M. K. (2020). COVID-19 and Indonesia. Acta Medica Indonesiana, 52(1), 84-89.

Smith, J. A., Flowers, P., \& Larkin, M. (2009). Interpretative Phenomenological Analysis Method and Research. SAGE Publications Ltd.

Starks, H., \& Trinidad, S. B. (2007). Choose your methodL A comparison of phenomenology, discourse analysis, and grounded theory. Qualitative Health Research, 17(10), 1372-1380. https://doi.org/ 10.1177/1049732307307031

Sulistiadi, W., Rahayu, S., \& Harmani, N. (2020). Handling of public stigma on COVID-19 in Indonesian society. Kesmas: Jurnal Kesehatan Masyarakat Nasional (National Public Health Journal), 1. https://doi.org/10.21109/kesmas.v15i2.3909

Sun, N., Sun, L. W., Shi, S., Jiao, D., Song, R., Ma, L., Wang, H., Wang, C., Wang, Z., Ypu, Y., Liu, S., \& Wang, H. (2020). A qualitative study on the psychological experience of caregivers of COVID-19 patients. American Journal of Infection Control, 48, 592-598. https://doi.org/10.1016/j.ajic.2020.03.018

Sun, N., Wei, L., Wang, H., Wang, X., Gao, M., Hu, X., \& Shi, S. (2021). Qualitative study of the psychological experience of COVID-19 patients during hospitalization. Journal of Affective Disorders, 278, 15-22. https://doi.org/10.1016/j.jad.2020.08.040

Wango, G., \& Wairire, G. G. (2020). Anxiety and emotions of COVID-19: The emotional underpinnings of dealing with the corona virus disease.

World Health Organization. (2020). Situation by Country, Territory, \& Area. WHO Coronavirus Disease Dashboard. https://covid19.who.int/table

Yanuardi, M. S. (2017). Intolerance of uncertainty, social anxiety and alcohol use among students in the United Kingdom and Indonesia. Newcastle University. 